\title{
Genotype x Environment Interaction and Yield Stability of Maize
}

\author{
Mosisa Worku ${ }^{1}$ and Habtamu Zelleke2* \\ ${ }^{1}$ Ethiopian Institute of Agricultural Research, Bako Agricultural Research Centre, P O Box 3, Ethiopia \\ ${ }^{2}$ Haramaya University, College of Agriculture, Department of Plant Sciences, P O Box 147, Ethiopia
}

\begin{abstract}
Maize cultivars vary in their response to variable environmental conditions. Twenty maize cultivars were tested at nine locations in Ethiopia $(1100$ - 2240 masl $)$ in randomized complete block design with three replications for two years to study the nature and magnitude of genotype $x$ environment $(G \times E)$ interaction and phenotypic yield stability of the cultivars. Analysis of variance and stability analysis were computed. Variances due to genotypes, years, locations, genotype $\mathrm{x}$ year, genotype $\mathrm{x}$ location and genotype $\mathrm{x}$ year $\mathrm{x}$ location interaction were significant $(\mathrm{P}<0.01)$. Most of the cultivars had significant deviation mean square $\left(\mathrm{S}^{2} \mathrm{di}\right)$, implying that these cultivars had unstable performance across the testing environments. However, Additive Main Effect and Multiplicative Interaction (AMMI) analysis showed Gibe-1 (mean yield, $7.40 \mathrm{t} \mathrm{ha}^{-1}$ ) had relatively stable performance across the environments. None of the cultivars were the best for grain yield in all environments. BH-660 (mean grain yield, $8.14 \mathrm{tha}^{-1}$ ) had a relatively good performance in the mid- to high-altitude $(1650-2240$ $\mathrm{m}$ above sea level) areas whereas BH-140 (mean grain yield, $6.65 \mathrm{t} \mathrm{ha}^{-1}$ ) had a good performance in the low-mid to mid-altitude $(1100-1650 \mathrm{~m}$ above sea level) areas, indicating the possibility of developing specific cultivars adapted to mid- and high- or low-mid and mid-altitude areas. However, the top yielding cultivars at each maize agro-ecology were specifically adapted, indicating that, for high yield potential in each maize agro-ecology, a specific breeding program is necessary.
\end{abstract}

Keywords: Environment; Cultivar; Interaction; Stability; Zea mays

\section{Introduction}

Changes in relative rankings appear to be an inevitable consequence of growing a set of plant genotypes in even a few locations or seasons. This is especially true in tropical regions where, not only are environmental fluctuations greater, but crops also lack the protection conferred by purchased inputs; thus for plant breeders, large genotype by environment $(\mathrm{G} \times \mathrm{E})$ interactions impede progress from selection and have important implications for testing and cultivar release programs (Smithson and Grisley, 1992).

In fact, $G \times E$ interaction is as much a function of the genotype as they are of the environment and so are partly heritable (Hill, 1975). Statistically, G x E interactions are detected as significantly different patterns of response among the genotypes across environments and biologically, this will occur when the contributions (or level of expression) of the genes regulating the trait differ among environments (Basford and Cooper, 1998).

As it is a common phenomenon in the East of Africa (Birhane and Bentayehu, 1989), Ethiopia is a country of great environmental variation (EMA, 1988). Where environmental differences are greater, it may be expected that the $G \times$ E interaction will also be greater. As a result, it is not only average performance that is important in genotype evaluation programs but also the magnitude of the interactions (Fehr, 1992; Gauch and Zobel, 1997). Stability of performance is also of special importance in Ethiopia and similar countries where environmental conditions vary considerably and means of modifying the environment are far from adequate. Benti et al. (1996) studied G $x$ E interaction and grain yield stability of twelve maize composites and three locally-adapted Kenyan hybrids at six locations in Ethiopia with altitude ranges of 1100 - 1750 meters above sea level (masl) with sufficient rainfall for two years and found $G \times E$ interaction. Wende et al. (2004) also studied the G x E interaction of ten locally-developed maize cultivars at five locations $(1650$ - 2240 masl $)$ in Ethiopia for three years and reported $G \times \mathrm{E}$ interaction. However, it is not possible to get information on the performance of the maize cultivars across the altitude ranges of $1100-2240$ masl, the major sub-humid maize growing areas of Ethiopia. Thus, this study intended to study the nature and magnitude of $G \times \mathrm{E}$ interaction and grain yield stability of twenty maize cultivars at nine locations (1100 - 2240 masl) in Ethiopia for two years.

\section{Materials and Methods}

Twenty different maize cultivars of East African and CIMMYT origin were tested at nine locations situated between $7^{\circ} 09^{\prime} \mathrm{N}$ and $11^{\circ} 16^{\prime} \mathrm{N}$ latitudes and $36^{\circ} 00^{\prime} \mathrm{E}$ and 42 02' $\mathrm{E}$ longitudes in the 1997 and 1998 main cropping seasons. The altitude and annual rainfall of the locations ranged from 1100 - 2240 meters above sea level (masl) and 900 - $1595 \mathrm{~mm}$ respectively. The testing locations were: Pawe (1100 masl), Bako (1650 masl), Awassa (1700 masl), Jimma (1750 masl), Areka (1800 masl), Arsi-Negelle (1960 masl), Alemaya (1980 masl) and Adet $(2240$ masl). The locations represent three of the four major maize-producing mega-environments in Ethiopia; viz. low (low-mid) altitude sub-humid zone, mid-altitude sub-humid zone and high altitude sub-humid zone (Birhane and Bantayehu, 1989; Benti et al., 1993).

The cultivars were planted at each location in randomized complete block design with three replications. The experimental unit was a two row plot 5.1 meters long, spaced $75 \mathrm{~cm}$ apart and with a plant-to-plant

*Corresponding author. E-mail: habtaamu@yahoo.com 
distance of $30 \mathrm{~cm}$. All trial management practices were based on the recommendations of each location. Field weight was recorded from all ears in the harvest area. Then grain yield per hectare was calculated using average shelling percentage of $80 \%$ and adjusted to $12.5 \%$ moisture.

Analysis of variance for each environment and combined analysis of variance over years and locations were computed for grain yield. Bartlett's test, as cited in Gomez and Gomez (1984), was also computed to assess homogeneity of variances prior to combined analysis. The statistical significance of analysis of variance was determined using the F-test.

The stability of yield performance for each cultivar was calculated by regressing the mean yields of individual cultivar on environmental index and calculating the deviations from regression as suggested by Eberhart and Russell (1966). However, regression coefficient (bi) was considered as an indication of the response of the cultivar to varying environments while mean square for deviations from regression $\left(\mathrm{S}^{2} \mathrm{di}\right)$ was used as the criteria of stability as suggested by some authors (Gupta et al., 1974; Becker and Leon, 1988). In addition, the $G \times E$ interactions were analyzed using Additive Main effect and Multiplicative Interaction (AMMI) analysis (Crossa et al., 1990; Gauch, 1992) to assess similarity and dissimilarity among testing environments and interaction patterns.

The regression coefficients (bi) were tested for significant difference from unity using t-tests while the significance of the deviations from regression $\left(\mathrm{S}^{2} \mathrm{di}\right)$ from zero was tested by the F-test. The SAS computer program (SAS, 2001) and the AGROBASE software computer program (Agronomix software INC. and AGROBASE, 2000) were used for the analysis of the data.

\section{Results and Discussion}

Analysis of variance for grain yield revealed significant differences $(\mathrm{P}<0.01)$ among the cultivars in each environment. Variances due to genotypes $(\mathrm{G})$, years $(\mathrm{Y})$, locations (L), genotype $\mathrm{x}$ year, genotype $\mathrm{x}$ location and genotype $\mathrm{x}$ year $\mathrm{x}$ location were significant $(\mathrm{P}<0.01)$ (Table 1). The significance of the interaction effects showed that the cultivars had inconsistent performance across the years and locations. A similar result was reported by Lothrop (1989) in which he indicated that environmental changes cause $G \times \mathrm{E}$ interaction for grain yield.

The partitioning of variance components showed that $53.64 \%$ was due to Y x L interaction, $13.84 \%$ was due to location, while $8.06 \%$ was due to the genotypes (cultivars) (data not shown). This indicated that environment was the greatest source of variation. AMMI analysis also showed that the $G \times E$ interaction was significant $(\mathrm{P}<0.01)$ and the best-fit model was AMMI2 (Table 1). Interaction Principal Component Analysis score (IPCA1) was significant $(\mathrm{P}<0.01)$ and explained $29.06 \%$ of the $\mathrm{G} x$ $\mathrm{E}$ interaction sum of squares. Similarly, the Interaction Principal Component Analysis score (IPCA2) was significant $(\mathrm{P}<0.01)$ and explained $22.82 \%$. This showed that the two IPCAs accounted for the larger portion $(51.88 \%)$ of the total interaction.

AMMI biplots for grain yield (Figure 1) showed distinct patterns for the testing environments. The high-yielding environments, Alemaya 1997 (AL97), Hirna 1997 (HR97), Awassa 1998 (AW98), Adet 1998 (AD98), Pawe 1998 (PW98) and Bako 1997 (BK97), were in quadrants two and three while the low-yielding environments, Hirna 1998 (HR98), Alemaya 1998 (AL98), Adet 1997 (AD97), Areka 1998 (AR98) and Awassa 1997 (AW97) were in quadrants one and four. AMMI biplots showed that AD98 and AL97 were the most favorable environments for realizing the yield potential of the cultivars while HR98 was the poorest yielding environment. This showed that the performance of the cultivars varied from season to season in some locations.

The result of this experiment showed that the elevation rainfall distribution during the growing period (data not shown) had a great impact on the performance of maize cultivars. For example, Alemaya and Hirna were among the high yielding environments in 1997 whereas they were among the poor yielding environments in 1998 (Figure 1). This could be attributed to the continuous moisture stress after emergence due to shortage of rain in eastern Oromia in 1998. The stress occurred during the vegetative growth period while there was good distribution of rain during the grain filling period. This implied that the data obtained from the two locations in 1998 may not represent the actual yield potential of the normal years. The year effect was also observed at Adet and Awassa in 1997 (Figure 1). Thus, cultivars were exposed to different environments at the same location in different years. Similar results were reported by other authors (Fox and Rosille, 1982; Becker and Leon, 1988). This indicated the necessity of testing elite maize cultivars at least for two years before recommending them for commercial production, especially in areas where rainfall distribution is unreliable.

The mean grain yield of the cultivars across the 18 environments (year-location combination) ranged from $5.71 \mathrm{t} \mathrm{ha}^{-1}$ in Beletech RC-2 to $8.14 \mathrm{t} \mathrm{ha}^{-1}$ in BH-660 (Table 2). The ranking of the cultivars varied across the seasons in some locations and altitudinal ranges (data not shown). For example, BH-540 was among the lowyielding in 1997 at Alemaya, while it was the highest yielding in 1998, indicating G x Y interaction. BH-660 was the top-yielding at high altitude and had relatively good performance at mid-altitude testing locations. However, it was out-yielded by BH-530, BH-140 and Gibe-1 at Pawe, low-mid altitude sub-humid zone. Although, BH-530 was the top-yielding at Pawe, it was one of the low-yielding cultivars at the other testing locations, mid- and high-altitude sub-humid zones, whereas BH-140 and Gibe-1 had relatively good performances at low-mid and mid-altitude testing locations. This indicated that the rank of the cultivars varied from one testing location to another testing location, confirming the presence of $\mathrm{G} \times \mathrm{L}$ interaction. Similarly, Wende Abera et al. (2004) found 
Table 1. Combined analysis of variance and AMMI analysis for grain yield of 20 maize cultivars tested at nine locations over two years in Ethiopia (1997-1998).

\begin{tabular}{lll}
\hline Source & df & Mean square \\
\hline Year $(\mathrm{Y})$ & 1 & $127.54^{* *}$ \\
Location $(\mathrm{L})$ & 8 & $80.89^{* *}$ \\
Y x L & 8 & $313.61^{* *}$ \\
Replication $(\mathrm{L} x \mathrm{Y})$ & 36 & $1.88^{* *}$ \\
Genotype $(\mathrm{G})$ & 19 & $19.84^{* *}$ \\
Yx G & 19 & $2.71^{* *}$ \\
Lx G & 152 & $2.05^{* *}$ \\
Yx Lx G & 152 & $1.65^{* *}$ \\
Error & 684 & 0.49 \\
AMMI & & \\
Gx E & 323 & $1.90^{* *}$ \\
IPCA1 & 35 & $4.22^{* *}$ \\
IPCA2 & 33 & $3.52^{* *}$ \\
\hline
\end{tabular}

**_ Significant at $P<0.01$.

crossover interaction in maize cultivars tested in the mid and high-altitude areas of Ethiopia (1650 - 2240 masl). This showed that for high yield potential, a specific breeding program is necessary for the low- and highaltitude maize growing areas of Ethiopia. This is similar to the report of Rathore and Gupta (1994) who stated that the presence of crossover interaction is substantial evidence in favor of breeding for specific adaptation.

The superior performance of BH-660 at high elevations could be attributed to its genetic background as its parental lines are developed from Kitale Synthetic- II and Eucador-573, which are adapted to high-altitude transition zones (Benti et al., 1993). On the other hand, BH-530 with CIMMYT tropical maize germplasm in its genetic background (Benti et al., 1997) had a better performance at the lower elevations.

Analysis of responsiveness as measured by regression coefficients (bi) indicated that most of the cultivars had average responsiveness (Table 2). The high-yielding cultivars, BH-660 and Gibe-1 were more responsive (bi $>1$ ) to favorable environmental conditions than the other cultivars. The better response of Gibe-1, as compared to the other open-pollinated cultivars, indicated the possibility of developing open-pollinated cultivars with high mean grain yield under favorable environmental conditions. The old composites, Alemaya composite, $\mathrm{UCB}$ and Bako composite, had regression coefficients below unity $($ bi<1), indicating their average responsiveness to favorable environmental conditions. In addition, their grain yield means were less than the grand mean, which indicated their inferior performance compared to Gibe-1.

The simple correlation coefficient between mean yields and regression coefficients was calculated and it showed a positive relationship $(r=3)$ indicating the possibility of breeding responsive cultivars along with high grain yield. Abebe et al. (1984) also found a positive relationship between mean grain yields and regression coefficients in sorghum.

Most of the cultivars had significant deviation mean square from linear regression $\left(\mathrm{S}^{2} \mathrm{di}\right)$, implying that these cultivars were unstable across the environments (Table 2). $\mathrm{BH}-530$ had the highest $\mathrm{S}^{2}$ di. The high yielding cultivars, BH-660 and Gibe-1 also had significant S2di, implying unstable performance across the testing environments. In general, when the three adaptability parameters, i.e. mean yield, regression coefficient and deviation mean square from the linear regression were considered, none of the cultivars exhibited general adaptability. Additive Main effect and Multiplicative Interaction (AMMI) analysis also showed differences among the cultivars in their stability performance for grain yield across the testing environments (Table 2).

The closer the IPCA scores (Interaction Principal Component Analysis scores, IPCA1 and IPCA2) to zero, the more stable the cultivars are across the environments (Crossa et al., 1990; Purchase, 1997). When the IPCA scores were considered, Gibe-1 had relatively stable performance across the environments among the highyielding cultivars (Figure 1).

However, the good performance of $\mathrm{BH}-660$ in the midand high-altitude areas and good performance of BH-140 and Gibe-1 in the low-mid and mid altitude areas indicated the possibility of developing maize cultivars adapted to mid- and high-altitude or low-mid and midaltitude areas. Crossa et al. (1990) have also reported similar observations about the performance of specific maize genotypes across altitude ranges. 


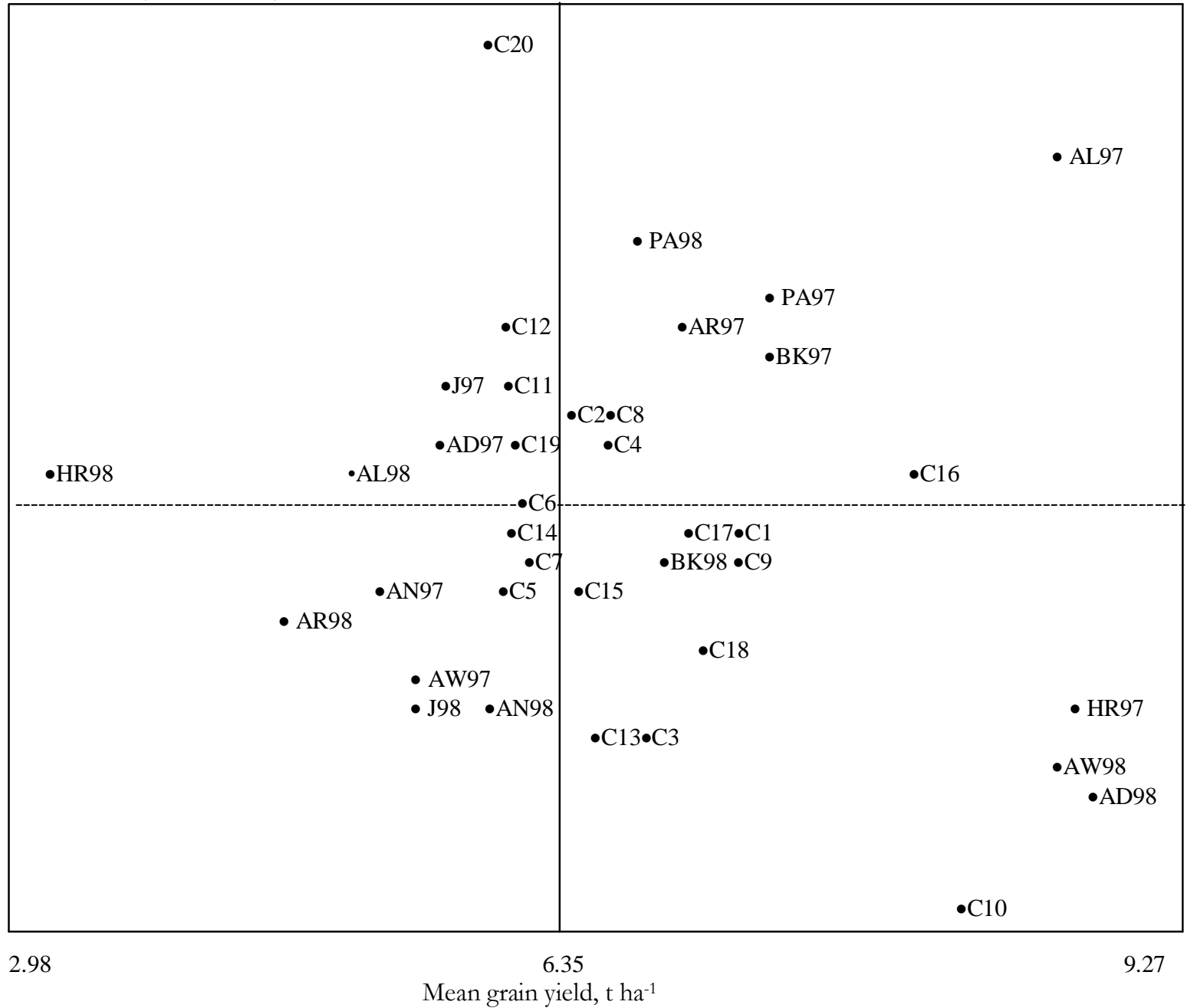

Figure 1. AMMI biplot for grain yield of 20 maize cultivars tested across 18 environments of Ethiopia (9 location, 2 years). Dots on the biplot indicate the correct spot. $C=$ Cultivar, $A L=$ Alemaya, $A D=A d e t, J=J i m m a, B K=B a k o$, $\mathrm{AN}=$ Arsi-Negele, $\mathrm{AW}=$ Awassa, $\mathrm{HR}=$ Hirna, $\mathrm{AR}=$ Areka, $\mathrm{PA}=$ Pawe.

The present results demonstrate that, even in areas with sufficient rainfall, elevation has a great impact on the performance of maize cultivars in Ethiopia. It also showed that some specific cultivars, which are adapted to mid- and high- or low-mid and mid-altitude areas, could be developed. However, for high yield potential, a specific breeding program is necessary for each maize-producing agro-ecology of Ethiopia.
The results also indicated that, in some areas, distribution of rainfall during the growing period is the determining factor for the performance of maize cultivars. Thus, in those areas with abnormal distribution of rain in some years, the testing of maize cultivars across the years may help in selecting cultivars which give good yield during the years with even distribution of rain and relatively good performance in a year of uneven distribution of rain. 
Table 2. Mean grain yield, regression coefficient (bi), mean square of deviation ( $\left.{ }^{2} \mathrm{di}\right)$ and Interaction Principal Component Analysis scores, IPCA1 and IPCA2, of 20 maize cultivars tested at 18 environments in Ethiopia (19971998).

\begin{tabular}{|c|c|c|c|c|c|c|}
\hline & Cultivar & Yield $\left(\mathrm{t} \mathrm{ha}^{-1}\right)$ & bi & $\mathrm{S}^{2} \mathrm{di}$ & IPCA1 & IPCA2 \\
\hline 1 & Alemaya Comp. RC-23 & 6.88 & 1.04 & $34.64 * *$ & -0.03 & -0.70 \\
\hline 2 & Alemaya Comp. ${ }^{2}$ & 6.18 & 0.85 & $13.53^{*}$ & 0.40 & 0.50 \\
\hline 3 & UCB RC- $2^{3}$ & 6.45 & 0.71 & $58.61 * *$ & -0.71 & 1.04 \\
\hline 4 & $\mathrm{UCB}^{2}$ & 6.31 & 0.89 & $24.85^{* *}$ & 0.18 & 0.39 \\
\hline 5 & Beletech RC-2 ${ }^{3}$ & 5.71 & 0.95 & $41.15^{* *}$ & -0.22 & -0.54 \\
\hline 6 & Beletech $\mathrm{S}_{1} \mathrm{C}_{1} \mathrm{RC}-2^{3}$ & 6.05 & 1.02 & 9.96 & 0.05 & -0.22 \\
\hline 7 & Beletech $^{2}$ & 5.99 & 1.09 & $17.46^{*}$ & -0.17 & -0.40 \\
\hline 8 & Late $\mathrm{RC}-5^{3}$ & 6.33 & 0.98 & $15.23^{*}$ & 0.32 & -0.11 \\
\hline 9 & Synthetic RC-33 & 6.67 & 1.21 & $52.36^{* *}$ & -0.18 & -1.17 \\
\hline 10 & BH- $660^{1}$ & 8.14 & 1.12 & $101.70^{* *}$ & -1.29 & -0.29 \\
\hline 11 & EAH-752 & 5.79 & 1.07 & $45.02 * *$ & 0.49 & 0.15 \\
\hline 12 & Bako Comp. ${ }^{2}$ & 5.81 & 0.89 & $48.60^{* *}$ & 0.58 & 0.64 \\
\hline 13 & Kuleni ${ }^{2}$ & 6.38 & 0.83 & $17.19^{*}$ & -0.65 & 0.57 \\
\hline 14 & INT-A ${ }^{3}$ & 5.87 & 1.03 & 13.09 & -0.09 & -0.10 \\
\hline 15 & INT-B $^{3}$ & 6.18 & 1.12 & 12.72 & -0.27 & -0.53 \\
\hline 16 & Gibe-12 & 7.40 & 1.21 & $30.79 * *$ & 0.13 & 0.23 \\
\hline 17 & BH-1401 & 6.65 & 1.03 & $31.83^{* *}$ & -0.05 & 0.48 \\
\hline 18 & BH-5401 & 6.76 & 0.87 & $52.80^{* *}$ & -0.45 & 0.94 \\
\hline 19 & $A-511^{2}$ & 5.78 & 1.13 & 7.26 & 0.20 & -0.21 \\
\hline 20 & BH-5301 & 5.80 & 0.96 & $158.87 * *$ & 1.76 & 0.09 \\
\hline & Mean & 6.35 & & & & \\
\hline & $\mathrm{CV} \%$ & 11.03 & & & & \\
\hline
\end{tabular}

\section{Acknowledgements}

The authors would like to express their sincere thanks and appreciation to Molla Aseffa, Gudeta Nepir, Dhinsa Dhuguma, Yohanis Tolessa and maize researchers at cooperating centers for their assistance in organizing and executing the field experiment. The authors also thank Dr. Benti Tolessa, Mr. Wende Abera, Dr. Girma Taye, Dr. Legesse Wolde and Prof. Dr. V.P. Gupta for their assistance and encouragement.

\section{References}

Abebe, M., Yilma, K. and Birhane, G. 1984. Genotype x environment interaction and yield stability in sorghum of intermediate maturity. Ethiopian Journal of Agricultural Sciences 4 (1):1-11.

Agronomix Software, Inc., and AGROBASE 1998 Addendum. 2000. AGROBASETM, 71 Waterloo St. Winnepeg, Manitoba, R3NNOS4, Canada.

Basford, K.E. and Cooper, M. 1998. Genotype x environment interactions and some considerations of their implications for wheat breeding in Australia. Australian Journal of Agricultural Research 4:153-174.

Becker, H.C. and Leon, J. 1988. Stability analysis in plant breeding. Plant Breeding 101:1-23.

Benti, T., Gezehegne, B. and Aseffa, A. 1996. Genotype x environment interaction and yield stability of maize cultivars. Ethiopian Journal of Agricultural Science 15 (12): pp. 1-7.

Benti, T., Tasew, G., Mosisa, W., Yigzaw, D., Kebede, M. and Gezahegne, B. 1993. Genetic improvement of maize in Ethiopia. In: Benti, T. and Ransom, J.K. (eds.). Proceedings of the First National Maize Workshop of Ethiopia. IAR/CIMMYT, Addis Ababa, Ethiopia. pp. 13-22.

Benti, T., Kebede, M., Legesse, W., Mosisa, W. and Leta, T. 1997. Reflections on the successful achievements of hybrid maize breeding program in Ethiopia. In: Ransom, J.K., Palmer, A.F.E., Zambezi, B.T., Maduruma, Z.O., Waddington, S.R., Pixley, K.V. and Jewell, D.C. (eds.). Maize Productivity Gains through Research and Technology Dissemination. Proceedings of the Fifth Eastern and Southern Africa Regional Maize Conference. 3-7 June 1996, Arusha, Tanzania. CIMMYT, Addis Abeba, Ethiopia. pp. 67-71.

Birhane, G. and Bentayehu, G. 1989. The maize megaenvironments of Eastern and Southern Africa. In: Birhane, G. and Bentayehu, G. (eds.). Proceedings of the Third Eastern and Southern Africa Regional Maize Workshop. 18-22 Sep. 1989, Nairobi, Kenya. CIMMYT, Kenya. pp. 75-94.

Crossa, J., Taba, S. and Wellhausen, E.J. 1990. Heterotic patterns among Mexican races of maize. Crop Science 30(6):1182-1190. 
Eberhart, S.A. and Russell, W.A. 1966. Stability parameters for comparing cultivars. Crop Science 6:3640.

Ethiopian Mapping Authority (EMA). 1988. National Atlas of Ethiopia. Addis Abeba, Ethiopia. pp. 4-21.

Fox, P.N. and Rosielle, A.A. 1982. Reference sets of genotypes and selection for yield in unpredictable environments. Crop Science 22(6):1171-1174.

Fehr, W.R. 1992. Principles of Cultivar Development Theory and Technique. IOWA State University, USA. pp. 247-260.

Gauch, H.G. 1992. Statistical Analysis of Regional Yield Trials: AMMI Analysis of Factorial Designs. Elsevier, New York. pp. 21-60

Gauch, H.G. and Zobel, R.W. 1997. Identifying megaenvironments and targeting genotypes. Crop Science 37(2):311-326.

Gomez, K.A. and Gomez, A.A. 1984. Statistical Procedures for Agricultural Research. John Willey and Sons, New York. pp. 467-471.

Gupta, V.P., Ramanujam, S. and Kaul, A.K. 1974. Stability analysis in respect of protein sulphur and protein value index of seed and its implication in adaptation of chick pea. Genetika 6(2):247-261.

Hill, J. 1975. Genotype x environment interaction: A challenge for plant breeding. Journal of Agricultural Science 85:477-493.
Lothrop, J.E., 1989. The CIMMYT head quarter high land maize program. In: Birhane, G. and Bentayehu, G. (eds.). Proceedings of the Third Eastern and Southern Africa Regional Maize Workshop. 18-22 Sep. 1989, Nairobi, Kenya. CIMMY'T, Kenya. pp. 75-94.

Purchase, I.L. 1997. Parametric analysis to describe genotype by environment interaction and yield stability in winter wheat. Ph.D. Thesis. Department of Agronomy, Faculty of Agriculture, University of the Orange Free State, Bloemfontein, South Africa.

Rathore, P.K. and Gupta, V.P. 1994. Crossover and noncrossover interactions and regression analysis for seed yield and its components in pea. Crop Improvement 21(1):14-18.

SAS Institute. 2001. The SAS System for Windows Release 8.02. SAS Institute INC., Cary, NC.

Smithson, J.B. and Grisely, W. 1992. First African bean yield and adaptation nursery: Part II. Performance across environments. Network on Bean Research in Africa, Occasional Publication Series No. 3B. CIAT Dares Salaam, Tanzania.

Wende, A., Van Rensburg, J.B.J., Labuschagne, M.T., Maartens, H. 2004. Genotype x environment interactions and yield stability analyses of maize in Ethiopia. South African Journal of Plant and Soil 21 (4): pp. 251-254. 